\title{
Simple Decompression of the Ulnar Nerve at the Elbow Via Proximal and Distal Mini Skin Incisions
}

\author{
Dirsekte Ulnar Sinir Tuzaklanmasinın Proksimal ve Distal Mini \\ Insizyonlar ile Basit Dekompresyonu
}

Tarkan CALISANELLER ${ }^{1}$, Ozgur OZDEMIR ${ }^{1}$, Hakan CANER ${ }^{2}$, Nur ALTINORS²

${ }^{1}$ Baskent University, Faculty of Medicine, Department of Neurosurgery, Konya, Turkey

${ }^{2}$ Baskent University, Faculty of Medicine, Department of Neurosurgery, Ankara, Turkey

Correspondence address: Tarkan CALISANELLER / E-mail: tarkan_ca@yahoo.com

\begin{abstract}
The purpose of the present study was to describe a new minimally invasive surgical technique for decompression of the ulnar nerve at the elbow for treatment of cubital tunnel syndrome. Four patients underwent surgical treatment for cubital tunnel syndrome. Preoperative clinical states were classified by using the McGowan grading system and the postoperative states were recorded by using the Wilson and Krout grading system. Preoperative and last follow-up electromyographic results were also recorded. At the last follow-up, three patients were recorded as excellent and one patient was recorded as good according to Wilson and Krout grading system. One patient showed improvement in sensory nerve conduction velocity another showed improvement in motor nerve conduction velocity at the last follow-up. We conclude that simple decompression of the ulnar nerve at elbow via proximal and distal mini skin incisions is an effective, technically simple and safe surgical method in the treatment of cubital tunnel syndrome.
\end{abstract}

KEYWORDS: Cubital tunnel syndrome, Minimally invasive surgery, Ulnar nerve decompression

öz

Bu çalışmada Kubital Tünel Sendromunun tedavisi amacıyla ulnar sinirin dirsekte dekompresyonu için yeni bir minimal invaziv cerrahi teknik tanımlanmıştır. Kübital Tünel Sendromu olan dört hasta cerrahi olarak tedavi edilmiştir. Hastaların ameliyat öncesi klinik durumları McGowan derecelendirme sistemine göre ve ameliyat sonrası durumları Wilson ve Krout derecelendirme sistemine göre belirlenmiştir. Ek olarak hastalara ait ameliyat öncesi ve son kontroldeki elektrofizyolojik çalışmalar da incelenmiştir. Son kontrollerinde, Wilson ve Krout derecelendirme sistemine göre üç hastanın durumu mükemmel ve bir hastanın durumu iyi olarak tespit edilmiştir. Yine son kontrolde, bir hastada duyu sinir iletim hızında ve başka bir hastada motor sinir iletim hızında düzelme tespit edilmiştir. Sonuç olarak dirsekte ulnar sinir tuzaklanmasının proksimal ve distal mini insizyonlar ile dekompresyonu basit, efektif ve güvenli bir metod olarak bulunmuştur.

ANAHTAR SÖZCÜKLER: Kübital tünel sendromu, Minimal invaziv cerrahi, Ulnar sinir dekompresyonu

\section{INTRODUCTION}

The cubital tunnel syndrome is the second most frequent entrapment neuropathy in the upper extremity in adults $(6,14)$. Although numerous etiologies including external trauma, pressure, bone impingement, irregularities in muscles, subluxation of ulnar nerve, ganglia and severe cubitus valgus deformity have been proposed for the pathophysiology of cubital tunnel syndrome, the majority of the cases are idiopathic $(16,19,27)$.

Conservative therapy is recommended for mild cases (4). However, more severe cases with no improvement after conservative therapy or cases developing new muscle weakness are candidates for surgical treatment (19). Surgical options for these patients consist of simple decompression with or without medial epicondylectomy, and transposition procedures (7).
The traditional simple decompression of the ulnar nerve requires a relatively long skin incision of 6-8 cm, above and below the elbow. We have performed in-situ decompression of the ulnar nerve at the elbow through proximal and distal mini skin incisions and report the clinical and surgical results of this new method.

\section{MATERIAL and METHODS}

Four patients underwent surgical treatment for cubital tunnel syndrome in our department in 2007. The mean age of the patients was $41.25 \pm 9.91$ years (range 28-51 years) and the gender distribution was two female and two male. The mean duration of symptoms was $12.5 \pm 4.04$ months (range 9-18 months) and, the mean follow-up time was $13.75 \pm 1.7$ weeks (range 12-16 weeks). The diagnosis of cubital tunnel syndrome was based on physical examination and electrodiagnostic study. None of the patients had compressive ulnar neuropathy 
at another site (cervical radiculopathy, thoracic outlet or Guyon's canal syndrome), angular deformity at the elbow or a systemic disease such as diabetes mellitus or chronic renal failure.

Preoperative clinical states of the patients were classified by the McGowan grading system (24). In this classification system, patients with mild occasional paraesthesia, positive Tinel's sign and subjective weakness are grade-l, patients with moderate paraesthesia, objective weakness and positive Tinel's sign are grade-Il and, patients with severe constant paraesthesia, objective weakness and overt muscle wasting are grade-III. According to this classification all of our patients were recorded as grade-II.

Postoperative clinical states of the patients were recorded using the Wilson and Krout grading system (30). Patients with minimal motor and sensory complaints were graded as excellent, patients with occasional ache and mild sensory and motor complaints were graded as good, patients with improved but persistent sensory and motor complaints were graded as fair, and patients with no improvement or a worsened condition were graded as poor. In addition to clinical grading, postoperative follow-up electromyographic studies were also performed.

The operative procedure was performed under axillary regional anesthesia without using a tourniquet. We used 1-gram intravenous cephazoline-sodium for each procedure. The arm was abducted and externally rotated with the elbow flexed to about 60 degrees. A traditional 6-8 centimeters long curved (loose omega) skin incision centering anterior to the medial epicondyle and, extending above and below the elbow was marked using a sterile surgical pen (Figure 1A). Next, two skin incisions (2-centimeters each), at both the proximal and distal end of the marked line were performed (Figure 1B). The dissection was performed through the subcutaneous tissue. First, skin edges of the proximal incision were elevated by hooks and/or retractors and gently retracted towards ulnar sulcus between the medial epicondyle and olecranon, and the ulnar nerve was identified by dividing the Osborne ligament. Then, the ulnar nerve was followed proximally until it was released as it passed through the medial intermuscular septum. Next, the ulnar nerve was followed subcutaneously towards distal skin incision. Under the distal skin incision, the nerve was released by cutting the cubital tunnel retinaculum and flexor carpi ulnaris aponeurosis allowing the complete simple in-situ ulnar nerve decompression at the elbow (Figure 1C). After careful hemostasis, the wounds were closed in the usual manner. We did not use postoperative splints and the patients were encouraged to return to daily activities two weeks after the operation.

\section{RESULTS}

Demographic data of the patients, details of their history with clinical and electrodiagnostic tests, preoperative and postoperative grades are presented in Table I.

Clinically, three of the four patients were recorded as excellent and one patient was recorded as good according to Wilson and Krout grading system at the last follow-up. The patient graded as good (Case-4) was the eldest patient in this study with the longest history of complaints.

In the final follow-up electrodiagnostic tests, one patient showed improvement in sensory nerve conduction velocity (SNCV) and one patient showed improvement in motor nerve conduction velocity (MNCV).

No early or late postoperative complications such as loss of sensibility around scar, infection, seroma or dehiscence of wound was observed in any of the patients.

\section{DISCUSSION}

Cubital Tunnel Syndrome is the second most frequent entrapment neuropathy in the upper extremity in adults. During its course in the arm and forearm, the ulnar nerve can be compressed at four potential sites (Figure 2) (27). The first site is in the arm where the ulnar nerve pierces the medial intermuscular septum and emerges from under the arcade of Struthers, that is located at approximately $8-\mathrm{cm}$. proximal to the medial epicondyle. The second potential site of compression is the ulnar groove between olecranon and medial epicondyle. The third site is the humeroulnar arcade (or the cubital tunnel), and the last potential site of entrapment is the exit point between the two heads of flexor carpi ulnaris. The roof of the cubital tunnel is a thick fibrous aponeurosis (arcuate ligament of Osborne) that connects the humeral

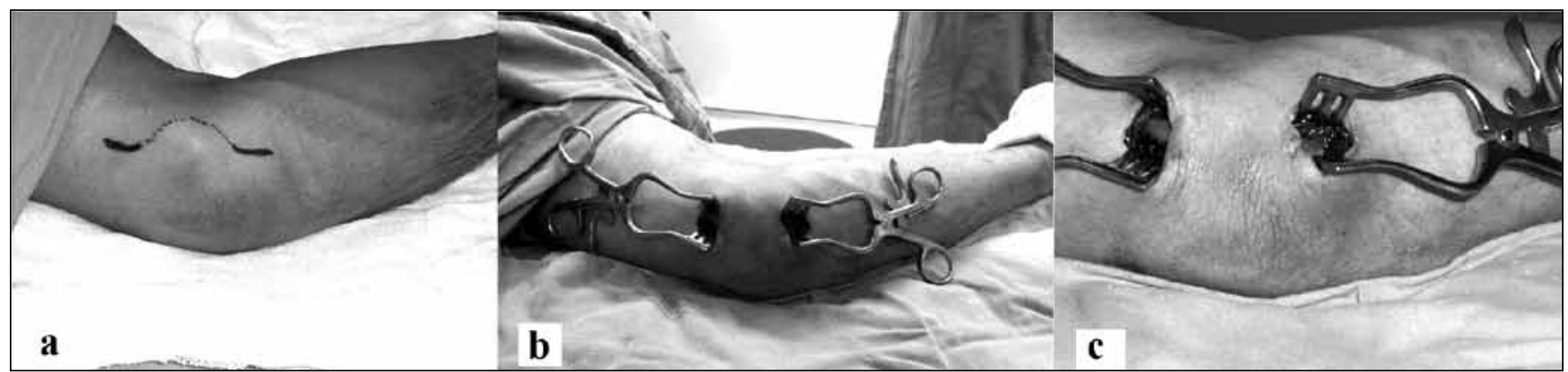

Figure 1: Operative view of the traditional loose omega type skin incision A), proximal and distal mini skin incisions B) and the ulnar nerve $\mathbf{C}$ ) at elbow. 
Table I: Summary of the Patients that Underwent Simple Ulnar Nerve Decompression Via Proximal and Distal Mini Skin Incisions

\begin{tabular}{|c|c|c|c|c|c|c|c|}
\hline $\begin{array}{l}\text { Case } \\
\text { no }\end{array}$ & $\begin{array}{l}\text { Age/ } \\
\text { Sex }\end{array}$ & $\begin{array}{l}\text { Duration of } \\
\text { symptoms } \\
\text { (months) }\end{array}$ & $\begin{array}{l}\text { Preoperative } \\
\text { grade in the } \\
\text { McGowan } \\
\text { system }\end{array}$ & $\begin{array}{l}\text { Postoperative } \\
\text { grade } \\
\text { in the Wilson and } \\
\text { Krout system }\end{array}$ & $\begin{array}{l}\text { Follow- } \\
\text { up } \\
\text { (weeks) }\end{array}$ & $\begin{array}{l}\text { Preoperative } \\
\text { SNCV/MNCV }\end{array}$ & $\begin{array}{l}\text { Postoperative } \\
\text { SNCV/MNCV }\end{array}$ \\
\hline 1 & $28 / F$ & 13 & Grade-II & Excellent & 12 & $\begin{array}{l}\text { SNCV : abnormal } \\
\text { MNCV: normal }\end{array}$ & $\begin{array}{l}\text { SNCV : abnormal } \\
\text { MNCV: normal }\end{array}$ \\
\hline 2 & $40 / M$ & 10 & Grade-II & Excellent & 16 & $\begin{array}{l}\text { SNCV : abnormal } \\
\text { MNCV: abnormal }\end{array}$ & $\begin{array}{l}\text { SNCV : abnormal } \\
\text { MNCV: normal }\end{array}$ \\
\hline 3 & $46 / \mathrm{M}$ & 9 & Grade-II & Excellent & 14 & $\begin{array}{l}\text { SNCV : abnormal } \\
\text { MNCV: abnormal }\end{array}$ & $\begin{array}{l}\text { SNCV : normal } \\
\text { MNCV: abnormal }\end{array}$ \\
\hline 4 & $51 / F$ & 18 & Grade-II & Good & 13 & $\begin{array}{l}\text { SNCV : abnormal } \\
\text { MNCV: abnormal }\end{array}$ & $\begin{array}{l}\text { SNCV: abnormal } \\
\text { MNCV: abnormal }\end{array}$ \\
\hline
\end{tabular}

SNCV: sensory nerve conduction velocity, MNCV: motor nerve conduction velocity.

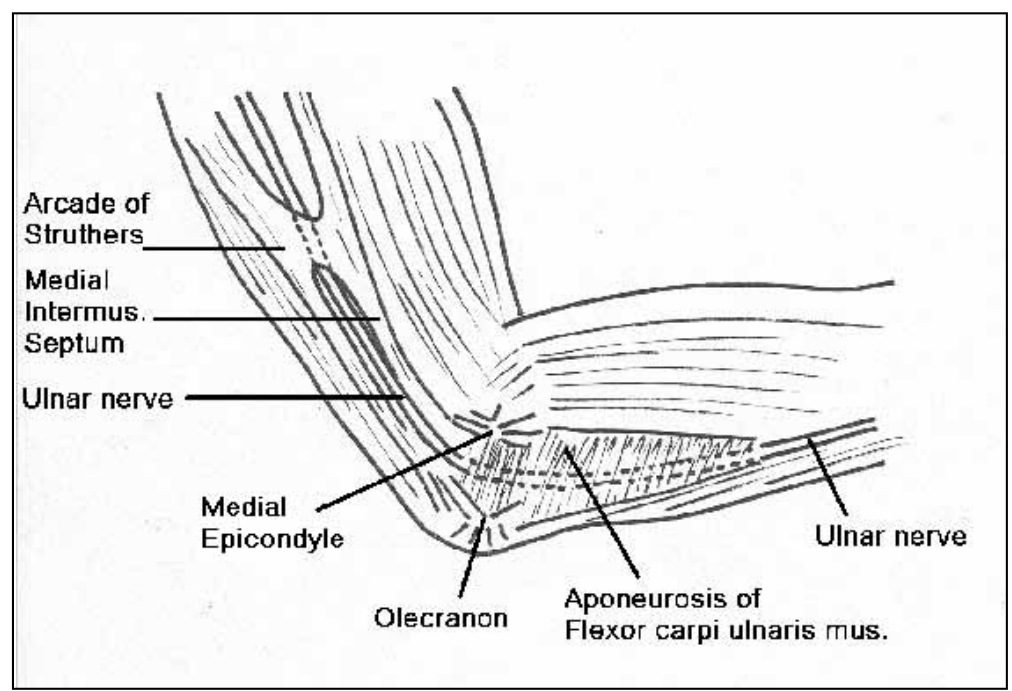

Figure 2: Schematic drawing of the potential compression sites of the ulnar nerve at elbow.

and ulnar heads of flexor carpi ulnaris muscle. The floor of the cubital tunnel is formed by the medial collateral ligament and the joint capsule. The medial epicondyle and the olecranon form the walls of the cubital tunnel. The most distal site of compression of the ulnar nerve occurs approximately 5 to 7-cm. distal to the medial epicondyle.

The treatment of cubital tunnel syndrome is controversial. Initial non-operative treatment including patient education, elbow splinting and non-steroidal anti-inflammatory medication has been shown to be effective in mild cases. Surgery is indicated for the failed cases of conservative treatment and for the patients who present with weakness, atrophy, or significant denervation on electromyogram $(3,8)$. Surgical options consist of simple decompression with or without medial epicondylectomy, or anterior subcutaneous, intramuscular and submuscular transposition procedures (3). The aims of the surgical treatment are to release all possible compression sites, to preserve the vascularity of the ulnar nerve, and to allow early mobilization of the elbow (27). Simple decompression is recommended for patients that exhibit mild symptoms, for patients with abnormal electrodiagnostic studies and for patients without subluxation of the ulnar nerve $(10,12,15,27)$.

In accordance with the surgical objectives described above, simple decompression has several advantages: it is technically simple and safe, it does not influence the blood supply of the nerve and it also allows early postoperative rehabilitation $(9,17,25)$. The traditional simple decompression of ulnar nerve requires a relatively long, omega shaped skin incision of 6-8 cm, above and below the elbow. Potential complications of this incision include sensibility loss around the scar, dehiscence of the wound, infection and seroma, as well as an undesirable cosmetic appearance $(8,21)$. The most common cause of pain and sensibility loss following cubital tunnel surgery is injury to the branches of the medial antebrachial cutaneous nerve (MACN). The MCAN arises from the medial cord of the brachial plexus and it divides into two main branches in the upper arm. The anterior branch innervates the distal anterior forearm, antecubital fossa and ulnar side of anterior forearm. The posterior branch of the MACN, which is the most commonly injured branch during cubital tunnel surgery, travels anywhere from $6 \mathrm{~cm}$ proximally to $4 \mathrm{~cm}$ distally to the medial epicondyle and innervates the skin over the posterior olecranon and proximal half of the posterior ulnar forearm (22). There are also few numbers of small branches of the MACN crossing the ulnar nerve in the region of cubital tunnel. Avoiding these branches during surgery improves clinical success of the cubital tunnel surgery regardless of the surgical technique $(13,20)$. One of the best ways to avoid this complication is to understand the anatomy of MACN and its relations with medial epicondyle and the ulnar nerve, as well as careful surgical dissection. 
Endoscopic ulnar nerve release techniques have been used to minimize complications and to provide patients return their profession earlier. Tsai et al. used specifically designed glass tubes to house the endoscope and a meniscus knife and reported that endoscopic assistance is a safe and reliable technique for cubital tunnel surgery (28). Nakao et al. used three $5 \mathrm{~mm}$ skin incisions along the course of the ulnar nerve for endoscopic release of the nerve in the cubital tunnel and presented earlier return to work and daily activity of the patients without any neurovascular complications (26). Krihnan et al. reported their results with uniportal endoscopic ulnar nerve release and transposition through a single 15-20 $\mathrm{mm}$ skin incision located over ulnar sulcus and concluded that their method could be a simple and effective alternative to traditional open surgery (21). Hoffman et al. used an illuminated specula and endoscopes designed for ENT surgeons and face lifting. They used a $1.5-3 \mathrm{~cm}$ skin incision over the retrocondylar grove to release the ulnar nerve (18). They concluded that small incisions can cause inadequate nerve release and increased injury to MACN. More recently, Ahcan et al. used a $4 \mathrm{~mm}, 30^{\circ}$ standard endoscope with a custom made guiding-dissecting tool and successfully decompressed ulnar nerve at the elbow through a 3,5 cm incision over the medial epicondyle (1). In addition to these clinical reports, few human cadaveric studies supported the safe and effective use of endoscopic techniques in the treatment of cubital tunnel syndrome $(5,23)$. However, endoscopic release of the ulnar nerve in the cubital tunnel has several drawbacks. For instance, using endoscopy provides only a two-dimensional and limited view of the surgical area and also requires special equipment and a learning curve $(21,29)$.

In this study, we used two small skin incisions at both end of a classical loose omega incision to decompress the ulnar nerve, in stead of a complete loose omega skin incision. In their human cadaveric study, Alp et al. reported that simple decompression of ulnar nerve at elbow through two limited skin incisions is anatomically possible with a very low incidence of ulnar nerve injury (2). However, to the best of our knowledge, no clinical application of this method has been reported so far. In this report, we have shown that we were able to decompress the ulnar nerve at the elbow effectively via proximal and distal two mini skin incisions. This new minimally invasive technique provided us the advantages of endoscopic technique such as small skin incisions and early return to daily activity, without the limitations of endoscopy such as two-dimensional view of the surgical field or need for special equipment and learning curve. The loose connective tissue structure of the arm enabled us to retract and elevate the skin incisions upward, proximally and distally. Therefore, we were able to reach and decompress all of the four potential compression sites of the ulnar nerve at elbow. Additionally, previous surgical experiences with familiarity to traditional open decompression and, observing the anatomy three-dimensionally allowed us to perform the surgery relatively easily. We observed no neurovascular complications in our patients. All of the four patients achieved satisfactory clinical results at the last follow-up time points. On the other hand, the good clinical results were not accompanied with improvements in the electrodiagnostic studies in the same degree. This can be explained by the short follow-up time in our study. Davis et al. have studied the safety and efficacy of submuscular transposition of ulnar nerve and its correlation with neurophysiological tests and, they reported that functional improvement is not always correlated with postoperative nerve conduction studies (11).

In conclusion, our experience showed that in situ (simple) decompression of the ulnar nerve at elbow via proximal and distal mini skin incisions can be an effective, technically simple and safe alternative surgical method in the treatment of cubital tunnel syndrome. The small number of the patients, lack of a control group and short follow-up time are the limitations of this study and our results should be reconfirmed in a randomized prospective controlled study.

\section{REFERENCES}

1. Ahcan U, Zorman P: Endoscopic decompression of the ulnar nerve at the elbow. J Hand Surg (Am) 32(8):1171-1176, 2007

2. Alp M, Akkin SM, Yalçin L, Marur T, Babacan M: Cubital tunnel release with two limited incisions: A cadaver study. Surg Radiol Anat 26(4):259-262, 2004

3. Asamoto $S$, Böker DK, Jödicke A: Surgical treatment for ulnar nerve entrapment at the elbow. Neurol Med Chir (Tokyo) 45(5):240-244; discussion 244-245, 2005

4. Baek GH, Kwon BC, Chung MS: Comparative study between minimal medial epicondylectomy and anterior subcutaneous transposition of the ulnar nerve for cubital tunnel syndrome. J Shoulder Elbow Surg 15(5):609-613, 2006

5. Bain $\mathrm{Gl}$, Bajhau A: Endoscopic release of the ulnar nerve at the elbow using the Agee device: A cadaveric study. Arthroscopy 21(6):691-695, 2005

6. Bartels RH, Menovsky T, Van Overbeeke JJ, Verhagen WI: Surgical management of ulnar nerve compression at the elbow: An analysis of the literature. J Neurosurg 89(5):722-727, 1998

7. Bartels RH: History of the surgical treatment of ulnar nerve compression at the elbow. Neurosurgery 49(2):391-399; discussion 399-400, 2001

8. Bartels RH, Verhagen WI, van der Wilt GJ, Meulstee J, van Rossum LG, Grotenhuis JA: Prospective randomized controlled study comparing simple decompression versus anterior subcutaneous transposition for idiopathic neuropathy of the ulnar nerve at the elbow: Part 1. Neurosurgery 56(3):522-530; discussion 522-530, 2005

9. Bednar MS, Blair SJ, Light TR: Complications of the treatment of cubital tunnel syndrome. Hand Clin 10(1):83-92, 1994

10. Cho YJ, Cho SM, Sheen SH, Chpi JH, Huh DH, Song JH: Simple decompression of the ulnar nerve for cubital tunnel syndrome. J Korean Neurosurg Soc 42:382-387, 2007

11. Davis GA, Bulluss KJ: Submuscular transposition of the ulnar nerve: Review of safety, efficacy and correlation with neurophysiological outcome. J Clin Neurosci 12(5):524-528, 2005

12. Dellon AL: Review of treatment results for ulnar nerve entrapment at the elbow. J Hand Surg (Am) 14(4):688-700, 1989 
13. Dellon AL, MacKinnon SE: Injury to the medial antebrachial cutaneous nerve during cubital tunnel surgery. J Hand Surg (Br) 10:33, 1985

14. Fernandez E, Pallini R, Lauretti L, Scogna A, La Marca F: Neurosurgery of the peripheral nervous system: Cubital tunnel syndrome. Surg Neurol 50(1):83-85, 1998

15. Foster RJ, Edshage $\mathrm{S}$ : Factors related to the outcome of surgically managed compressive ulnar neuropathy at the elbow level. J Hand Surg (Am) 6(2):181-192, 1981

16. Gabel GT, Amadio PC: Reoperation for failed decompression of the ulnar nerve in the region of the elbow. J Bone Joint Surg Am 72(2):213-219, 1990

17. Heithoff SJ: Cubital tunnel syndrome does not require transposition of the ulnar nerve. J Hand Surg (Am) 24(5):898-905, 1999

18. Hoffmann R, Sieminow M: The endoscopic management of cubital tunnel syndrome. J Hand Surg (British and European) 31B(1):23-29, 2006

19. Huang JH, Samadani U, Zager EL: Ulnar nerve entrapment neuropathy at the elbow: Simple decompression. Neurosurgery 55(5):1150-1153, 2004

20. Jackson LC, Hotchkiss RN: Cubital tunnel surgery: Complications and treatment of failure. Hand Clin 12(2):449-456, 1996

21. Krishnan KG, Pinzer T, Schackert G: A novel endoscopic technique in treating single nerve entrapment syndromes with special attention to ulnar nerve transposition and tarsal tunnel release: Clinical application. Neurosurgery 59(1):ONS89-100; discussion ONS89-100, 2006
22. Lowe JB, Maggi SP, Mackinnon SE: The position of crossing branches of the medial antebrachial cutaneous nerve during cubital tunnel surgery. Plast Reconstr Surg 114(3):692-696, 2004

23. Mariani PP, Golanò P, Adriani E, Llusà M, Camilleri G: A cadaveric study of endoscopic decompression of the cubital tunnel. Arthroscopy 15(2):218-222, 1999

24. McGowan AJ: The results of transposition of the ulnar nerve for traumatic ulnar neuritis. J Bone Joint Surg Br 32-B(3):293-301, 1950

25. Nabhan A, Ahlhelm F, Kelm J, Reith W, Schwerdtfeger K, Steudel WI: Simple decompression or subcutaneous anterior transposition of the ulnar nerve for cubital tunnel syndrome. J Hand Surg (Br) 30(5):521-524, 2005

26. Nakao Y, Takayama S, Toyama Y: Cubital tunnel release with lifttype endoscopic surgery. Hand Surg 6(2):199-203, 2001

27. Robertson C, Saratsiotis J: A review of compressive ulnar neuropathy at the elbow. J Manipulative Physiol Ther 28(5):345, 2005

28. Tsai TM, Bonczar M, Tsuruta T, Syed SA: A new operative technique: Cubital tunnel decompression with endoscopic assistance. Hand Clin 11(1):71-80, 1995

29. Tsai TM, Chen IC, Majd ME, Lim BH: Cubital tunnel release with endoscopic assistance: Results of a new technique. J Hand Surg (Am) 24(1):21-29, 1999

30. Wilson DH, Krout R: Surgery of ulnar neuropathy at the elbow: 16 cases treated by decompression without transposition. Technical note. J Neurosurg 38(6):780-785, 1973 